\title{
O POSITIVISMO JURÍDICO NORMATIVO NA PERSPECTIVA DE JEREMY WALDRON
}

\section{Cristina Foroni Consani ${ }^{1}$}

\section{Resumo}

Este artigo apresenta e discute o positivismo jurídico normativo a partir da teoria de Jeremy Waldron. Primeiramente, são apresentadas as principais tendência do positivismo jurídico contemporâneo, a saber: o positivismo jurídico nas propostas inclusiva, exclusiva e normativa. Em um segundo momento a análise concentra-se no positivismo jurídico normativo de Jeremy Waldron. São apresentados os argumentos do autor para a justificação da autoridade do direito, assim como a proposta metodológica do positivismo normativo que não se restringe a fazer uma descrição do direito positivo. Ao final, argumenta-se que a proposta de Waldron busca conectar o positivismo jurídico com a tradição política normativa e, desse modo, desenvolver uma teoria democrática do direito.

Palavras-chave: Jeremy Waldron, Teoria do Direito, Positivismo Jurídico Normativo, Democracia. Desacordos.

\section{INTRODUÇÃO}

Muitas críticas foram formuladas ao positivismo jurídico e aos seus principais postulados após a II Guerra Mundial. Uma das mais contundentes foi a crítica ao formalismo, segundo a qual o direito segundo critérios positivistas poderia abrigar injustiças tamanhas tais quais aquelas cometidas pelos regimes totalitários. Nesse contexto, ressurgiu nas teorias do direito o debate a respeito da reaproximação entre o direito e os ideais de justiça e de moralidade. Como uma reação às críticas, na segunda metade do século XX, principalmente a partir do final dos anos de 1970, o positivismo jurídico ganha novo fôlego e figura no debate contemporâneo a partir de três principais tendências ou perspectivas, a saber: o positivismo jurídico inclusivo, o positivismo jurídico exclusivo e o positivismo jurídico normativo.

O propósito deste artigo é apresentar e discutir, a partir da teoria de Jeremy Waldron, a proposta do positivismo jurídico normativo. $\mathrm{O}$ artigo está dividido em duas seções. Na primeira seção apresenta-se a discussão contemporânea no âmbito do positivismo jurídico e suas principais tendências, isto é, o positivismo jurídico

\footnotetext{
${ }^{1}$ Pós-Doutoranda em Direito (UFRN/PNPD- CAPES) e Professora Colaboradara no Departamento de Direito Público da Universidade Federal do Rio Grande do Norte (UFRN); Foi Visiting Scholar na Columbia University (2010). E-mail: crisforoni@yahoo.com.br
} 
inclusivo, o positivismo jurídico exclusivo e o positivismo jurídico normativo. O objetivo dessa seção não é deterse nos principais aspectos e discussões suscitadas por cada uma destas tendências, mas apenas apresentar o contexto no qual se insere a discussão do positivismo jurídico normativo e, principalmente, a teoria do direito defendida por Waldron. ${ }^{2}$ A segunda seção apresenta e analisa a teoria do direito de Waldron, fazendo-o em dois momentos: primeiramente, discorre-se sobre a teoria da democracia conforme defendida pelo autor e apresentase a sua justificação para a autoridade do direito; num segundo momento, mostra-se como o autor propõe uma teoria do direito democrática e a associa ao positivismo jurídico normativo.

O debate presente na teoria de Waldron é de grande relevância para se pensar a teoria do direito na atualidade, pois promove uma associação entre o positivismo jurídico e os valores democráticos, conexão esta bastante enfraquecida, seja pela associação da democracia a uma teoria dos direitos reforçada pelo poder judiciário (como na obra de Dworkin), seja pela recusa da conexão entre direito e política esposada pela Filosofia Analítica do Direito.

\section{O POSITIVISMO JURÍDICO CONTEMPORÂNEO E AS PERSPECTIVAS INCLUSIVA, EXCLUSIVA E NORMATIVA}

No âmbito da teoria do direito, a segunda metade do século XX foi particularmente significativa no que diz respeito à produção e discussão teórica. No início dos anos de 1960 Ronald Dworkin passou a tecer severas críticas ao positivismo jurídico, corrente até então dominante, sobretudo em razão da grande influência da obra de H.L.A Hart. A tese de Dworkin consagrou-se em 1977 com a publicação de Levando os direitos a sério, obra que causou grande impacto tanto pelas críticas oferecidas à obra de Hart, quanto pela proposta de um novo modelo teórico. ${ }^{3}$

Sem retornar às teses centrais do jusnaturalismo, Dworkin reivindica uma reconexão entre direito e moral, tese rejeitada pelo positivismo jurídico, e critica o positivismo jurídico em sua vertente hartiana em três principais pontos: primeiramente, a crítica recai sobre a regra de reconhecimento ou pedigree, isto é, a tese segundo a qual as regras jurídicas têm origem a partir de um procedimento que não tem a ver com o seu conteúdo, mas ao modo pelo qual foram elaboradas de acordo com uma norma superior (o que, eventualmente,

\footnotetext{
${ }^{2}$ Para uma discussão mais aprofundada a respeito do positivismo jurídico inclusivo e exclusivo, sugere-se a leitura dos seguintes autores: SEBOK, 1998; WALUCHOW, 1994; MARMOR, 2002. Esses textos realizam, em certa medida, uma reconstrução deste debate, de seus principais argumentos e propostas. Na literatura em língua portuguesa, Dimitri Dimoulis, em seu livro Positivismo Jurídico, apresenta estas e outras teorias positivistas contemporâneas realizando uma apreciação crítica de seus principais postulados (cf. DIMOULIS, 2006, p. 132-165); Em artigo recente, Delamar Volpato Dutra também discorre sobre o positivismo jurídico inclusivo e exclusivo, atribuindo ênfase às teses de Joseph Raz (cf. VOLPATO DUTRA, 2013, p. 193-209).

${ }^{3}$ A primeira grande crítica de Dworkin ao positivismo de Hart aparece em 1967, em um texto denominado The Model of Rules. Esse texto foi posteriormente incorporado ao livro Levando os direitos à sério (cap. 2). Cf. DWORKIN, 1967, p. 13-46. Contudo, Dworkin começou a desenvolver suas críticas ao positivismo jurídico já no início dos anos de 1960. Para uma reconstrução histórica da discussão do positivismo e seus críticos, ver SEBOK, 1998, p. 267ss.
} 
pode dar origem a uma lei injusta); a segunda crítica volta-se contra o poder discricionário do intérprete do direito nos casos de lacunas ou de casos difíceis que, no entendimento de Dworkin, não se trata de um poder discricionário em sentido fraco, como sustentado pelo positivismo jurídico, mas sim de um poder discricionário em sentido forte, que permite ao intérprete ir além do conjunto de regras existentes; a terceira grande crítica, bastante relacionada à anterior, foca-se na noção de obrigação jurídica, ou seja, para haver obrigação jurídica deve haver uma norma anterior que a estabeleça e, se o intérprete do direito decide uma matéria controversa exercendo um poder discricionário em sentido forte (criando novas regras), ele está propriamente criando uma obrigação jurídica que não existia anteriormente, haja vista não haver direito determinando-a. (cf. DWORKIN, 2002, p. 2772).

A bastante conhecida sugestão de Dworkin para evitar os problemas acima elencados é que o direito não seja considerado apenas como um conjunto de regras, conforme definição do positivismo jurídico, mas como composto por regras (válidas ou inválidas, aplicadas à maneira do tudo ou nada) e princípios (que possuem a dimensão do peso ou da importância e, portanto, nunca são inválidos, apenas aplicam-se ou não a determinado caso). Se os princípios forem tratados como direito, diz Dworkin, deve ser rejeitada a tese positivista "segundo a qual o direito de uma comunidade se distingue de outros padrões sociais através de algum teste que toma a forma de uma regra suprema." (DWORKIN, 2002, p. 70) Isso porque os princípios não entrariam no ordenamento jurídico segundo os critérios estabelecidos em outra regra (regra secundária), mas demandariam a aceitação e, na teoria hartiana, a única regra do sistema jurídico cuja obrigatoriedade depende de aceitação é a regra de reconhecimento. Logo, a admissão dos princípios, segundo Dworkin, faria ruir a tese de Hart segundo a qual somente a regra de reconhecimento é obrigatória em razão de sua aceitação (DWORKIN, 2002, p. 69).

Ademais, Dworkin parece mesmo acreditar ser inútil o apelo a uma regra superior no modelo da regra de reconhecimento, pois sustenta que em sistemas jurídicos complexos "nenhuma distinção definitiva pode ser feita entre padrões jurídicos e morais, como insiste o positivismo." (DWORKIN, 2002, p. 70). Essa afirmação tem implicações no que diz respeito à validade e à interpretação do direito, haja vista a moral tornar-se determinante em ambos os casos. Segundo Dworkin, aceitar que o direito é formado por regras e princípios permite mostrar que um juiz não cria o direito no momento de sua aplicação, mas ao contrário, apenas interpreta aquilo que já faz parte do direito existente em uma comunidade e dos valores morais com os quais um sistema jurídico se encontra comprometido.

Como uma reação às teses de Dworkin, a teoria do positivismo jurídico ganha novo fôlego, vindo até mesmo a ser chamada de "novo positivismo jurídico" (cf. SEBOK, 1998, 267). Para situar cronologicamente este debate entre positivismo e antipositivismo, Sebok menciona três estágios: o primeiro estágio tem início com a publicação, em 1961, da obra O conceito de Direito de Hart, considerado um momento de fundação do que vem 
sendo chamado de novo positivismo jurídico, haja vista as discussões e conflitos posteriores se darem em torno da interpretação da obra de Hart; o segundo estágio é marcado pela crítica de Dworkin a Hart; o terceiro estágio consiste nos esforços empreendidos por teóricos, a partir do final dos anos de 1970, para responder às críticas de Dworkin e aprimorar o trabalho de Hart. (cf. SEBOK, 1998, p. 268). Nesse terceiro estágio é possível identificar três principais perspectivas ou tendências, são elas: o positivismo jurídico inclusivo, o positivismo jurídico exclusivo e o positivismo jurídico normativo.

De um lado, há aqueles que focam no conceito de Hart de separação entre direito e moralidade e sustentam que o jurista inglês reconheceu que em alguns sistemas jurídicos a moralidade poderia ser uma condição da legalidade. Essa visão é conhecida como incorporacionismo ou positivismo jurídico inclusivo. Entre os autores que se filiam a este posicionamento podem ser mencionados o próprio Hart, que no Pós-escrito da segunda edição de $\mathrm{O}$ Conceito de Direito se mostrou simpático às teses incorporacionistas (denominadas por ele de "positivismo brando"), ${ }^{4}$ Jules Coleman ${ }^{5}$, W. J. Waluchow ${ }^{6}$ e Matthew Krammer ${ }^{7}$, entre outros. Waluchow define e explica os propósitos do positivismo jurídico inclusivo do seguinte modo:

\begin{abstract}
Segundo essa perspectiva, que temos chamado de positivismo jurídico inclusivo, valores morais e princípios estão entre os possíveis fundamentos que um sistema jurídico pode aceitar para determinar a existência e o conteúdo de leis válidas. Como um exemplo, pode-se considerar a possibilidade que a regra de reconhecimento de um sistema jurídico poderia conter explicitamente testes ou critérios para a validade jurídica da legislação do Congresso ou Parlamento. Se for possível para a regra de reconhecimento conter tais critérios, então a validade do direito poderia, em alguma ocasião, não ser determinada apenas pelo seu pedigree, isto é, pelo fato e modo de sua adoção. O simples fato de sua aprovação por uma legislatura soberana, por exemplo, seria insuficiente para determinar a validade jurídica da norma. Seríamos obrigados a decidir se ela viola uma condição moral, como a cláusula do devido processo na Declaração de Direitos Americana, que é interpretada por muitos como especificando a equidade como uma condição (moral) para a validade jurídica nos Estados Unidos. (WALUCHOW, 1994, p. 82)
\end{abstract}

Nas palavras de Kramer, esta perspectiva é inclusiva "porque permite que preceitos morais possam figurar em determinações oficiais do direito". (KRAMER, 2004, p. 2). Isso significa que em algumas sociedades pode haver uma convenção estabelecendo que se leve em consideração padrões morais para a determinação da validade e interpretação de normas jurídicas, mas não torna necessário que os critérios de validade e de interpretação estejam sempre atrelados à moralidade. Ainda nas considerações de Kramer, o inclusivismo é uma vertente do positivismo justamente porque os testes morais aos quais o sistema jurídico pode ser submetido "são contingentes, e não essenciais, de sistemas jurídicos em que são aplicados.” (KRAMER, 2004, p. 2). Nesse sentido,

\footnotetext{
${ }^{4}$ A esse respeito, ver HART, 2009, p. 316ss.

${ }^{5}$ As teses de Jules Coleman a este respeito podem ser encontradas em COLEMAN, 1998, p. 3-27; COLEMAN, 2001, p. 99-147.

${ }^{6}$ O posicionamento de W.J. Waluchow pode ser encontrado em WALUCHOW, 1994.

${ }^{7}$ A esse respeito, ver KRAMER, 2004.

${ }^{8}$ Tradução própria. Doravante, todas as traduções das obras citadas serão minhas, exceto quando nas referências bibliográficas for indicado distintamente.
} 
conforme exposto por Waluchow, para que uma norma jurídica seja submetida a um teste de moralidade este teste precisa estar previsto no próprio ordenamento jurídico.

De outro lado, há autores que defendem, também dialogando com a obra de Hart, a separação conceitual entre direito e moral e sustentam que a moralidade não pode ser uma condição da legalidade. Essa visão é denominada não incorporacionismo ou positivismo jurídico exclusivo. Dos autores que defendem esse posicionamento, destacam-se Joseph Raz ${ }^{9}$ e Andrei Marmor. ${ }^{10}$ Raz, que faz uso da expressão strong social thesis para denominar essa perspectiva do positivismo jurídico, a define do seguinte modo:

Uma teoria do direito é aceitável somente se seus critérios para identificar o conteúdo do direito e determinar sua existência dependerem exclusivamente de fatos da conduta humana capazes de serem descritos em termos valorativamente neutros e se aplicada sem recurso a argumentos morais. (RAZ, 1979, p. 39/40)

A recusa da moralidade como condição da legalidade feita pelo positivismo jurídico exclusivo também é feita de forma bastante clara na definição de Andrei Marmor:

(...) o positivismo exclusivo nega, enquanto o positivismo inclusivo aceita, que pode haver instâncias nas quais a determinação do que o direito é segue de considerações morais (...). $\mathrm{O}$ positivismo jurídico exclusivo sustenta que uma norma nunca se torna legalmente válida em virtude de seu conteúdo moral. A validade jurídica, de acordo com essa visão que me esforçarei para defender aqui, é inteiramente dependente de fontes do direito convencionalmente reconhecidas. (MARMOR, 2001, p. 49/50)

Para o positivismo jurídico exclusivo a moralidade não pode ser entendida como um critério de validade ou de interpretação de normas jurídicas. O direito é compreendido como fruto de uma convenção ou fato social (processo legislativo ou decisão judicial) que pode, é claro, incorporar preceitos da moralidade, mas esse fato social se torna direito em razão da autoridade que a vontade legislativa ou judicial possui e não em razão de estar ou não de acordo com a moralidade.

Há ainda uma terceira perspectiva, o positivismo jurídico normativo que, embora também ingresse na disputa a respeito de qual a melhor maneira de se compreender a relação entre o direito e a moral, não se restringe à discussão do positivismo de Hart, mas remonta às teses de Hobbes, Bentham e Austin. O positivismo jurídico normativo, também chamado de positivismo jurídico prescritivo ou ético ${ }^{11}$, tem como expoentes, entre outros, Tom Campbell ${ }^{12}$, Neil MacCormick ${ }^{13}$ e Jeremy Waldron. ${ }^{14}$ Trata-se de uma leitura segundo a qual o positivismo

\footnotetext{
${ }^{9}$ A esse respeito, ver RAZ, 1979 e também RAZ, 1986.

${ }^{10}$ A defesa do positivismo jurídico exclusivo na obra de Marmor pode ser encontrada em MARMOR, 2001.

${ }^{11}$ Essa nomenclatura é adotada por Tom Campbell: "O positivismo ético pressupõe o positivismo brando, sustentando que um sistema legal com propriedade conceitual, pode ou não incorporar a moralidade dentro de sua regra de reconhecimento, mas essa reivindicação é assessória para sua principal disputa que um sistema legal não deveria incluir critérios morais em sua lista oficial de fontes do direito. Essa é uma forma prescritiva, não uma forma analítica ou descritiva de positivismo duro ou exclusivo." (CAMPBELL, 2004, p. 26).

${ }^{12}$ Ver CAMPBELL, 2004.

${ }^{13}$ Ver, por exemplo, MAcCORMICK, 1985, p. 1-41.
} 
não é meramente uma descrição de como o direito é, mas é considerado normativo justamente por apresentar-se como uma prescrição a respeito do que o direito deve ser em uma sociedade democrática. Na definição dada por Campbell, essa versão da teoria positivista deve ser entendida como "uma teoria normativa que busca determinar o que o direito deve ser, não com respeito ao seu conteúdo, mas com respeito à sua forma" (CAMPBELL, 2004, p. 21).

Entre os autores que se filiam a essa perspectiva há variações no modo de relacionar as reivindicações normativas e o positivismo jurídico. Doravante, o positivismo jurídico normativo será analisado mais detalhadamente a partir da teoria de Waldron.

Waldron chama a atenção, tentando mesmo deslocar o foco da discussão predominante na teoria e na filosofia do direito contemporânea da interpretação de direitos, sobretudo dentro de cortes jurídicas, para a criação do direito por meio do processo legislativo. Ele procura mostrar que o espaço por excelência de discussão de valores morais, ideais de justiça e ideais políticos em desacordo é o espaço político e da política representativa dentro dos Parlamentos, ou seja, para que a política e a legislação tenham dignidade, é preciso cuidar da própria cultura política e jurídica. E isso, em seu entendimento, não é uma tarefa apenas da filosofia política, mas é uma exigência que se faz também para a filosofia do direito e para a teoria do direito.

\section{O POSITIVISMO JURÍDICO NORMATIVO NA TEORIA DE JEREMY WALDRON}

Os textos de Jeremy Waldron que melhor expressam sua filiação ao positivismo jurídico normativo são: Normative (or Ethical) Positivism (2001), The Core of the Case Against Judicial Review (2006) (15 $^{\mathrm{e}}$ Can there be a Democratic Jurisprudence? (2008). Contudo, para se mostrar a grande contribuição de suas teses, seja para a teoria do direito ou para a filosofia do direito, é preciso analisar esses textos em conjunto com outros, como por exemplo seu bastante influente livro Law and Disagreement (1999), de modo a ressaltar a principal preocupação em torno de sua teoria, a saber: como lidar com os desacordos a respeito de valores morais, políticos ou sobre justiça.

Waldron é um filósofo e jurista que se filia à tradição liberal ${ }^{16}$ e radicalmente democrática ${ }^{17}$. Ele tem empreendido em sua obra um grande esforço para delinear "uma teoria do direito que se sinta confortável com a

\footnotetext{
${ }^{14}$ Entre os textos de Waldron ver, especialmente, WALDRON, 1999; WADRON, 2001, p. 412-435; WALDRON, 2006, p. $1346-$ 1406 e WALDRON, 2008, p. 765-712.

${ }^{15}$ Nesse texto encontra-se uma forte crítica de Waldron ao papel do poder judiciário na interpretação de normas e, principalmente, no controle de constitucionalidade das leis. Embora seja um texto bastante relevante para entender o posicionamento do autor no que diz respeito à interpretação do direito, ele não será objeto de análise detalhada neste artigo.

${ }^{16} \mathrm{O}$ termo liberal aqui assume dois significados: primeiramente, refere-se à tradição liberal em sentido filosófico, isto é, à tradição que se reporta à John Locke e John Stuart Mill, defendendo-se a individualidade, as liberdades pessoais e de consciência e exigindose justificação para qualquer intervenção política do Estado; em segundo lugar, o termo liberal assume uma conotação política, conforme entendida no contexto norte-americano, isto é, o termo Liberal está atrelado à aceitação de "políticas públicas destinadas vol. 08, no. 04, Número Especial. Rio de Janeiro, 2015.pp. 2424-2448 
democracia", isto é, uma teoria do direito que ponha em prática o ideal de autogoverno, "rigorosa e detalhadamente, em sua explicação da natureza do direito, do fundamento da legitimidade, da tarefa de interpretação e das responsabilidades respectivas dos Parlamentos, dos cidadãos e dos tribunais de justiça." (WALDRON, 1999, p.9)

Sua proposta é justamente deslocar o foco da filosofia e da teoria do direito da interpretação judicial para a elaboração de leis dentro do poder legislativo. A legislação ocupa um lugar central em sua teoria. As leis, diz ele, "são essencialmente, e não apenas casualmente, o produto de assembleias amplas e polifônicas, e esta característica deveria ser crucial para nossa compreensão de como operar com as leis, isto é, de como interpretá-las e de como integrá-las no esquema mais amplo do direito." (WALDRON, 1999, p. 10)

Mas essa proposta não consistiria apenas em repetir uma perspectiva acrítica em relação ao direito, algo que já vinha sendo apontado, por exemplo, na teoria de Hans Kelsen? Esse é um aspecto bastante relevante e caro ao positivismo jurídico. Uma das principais críticas dirigidas a esta teoria, notadamente por autores que se filiam à teoria crítica do direito, é que o positivismo em sua pretensão de neutralidade fecha os olhos para o fato de o direito refletir os valores (morais, políticos, ideológicos ou de justiça) de grupos dominantes na sociedade, sejam eles os valores do livre mercado (crítica oferecida por autores vinculados ao marxismo e ao Critical Legal Studies), ou patriarcais (crítica feminista), ou raciais (crítica da teoria racial) ou mesmo a crítica às metanarrativas do direito (críticas pós-modernas às promessas de verdade, de justiça, de universalidade).

Waldron não se vincula a nenhum ponto de vista ingênuo. Ele reconhece que os Parlamentos são locais de desacordo, locais nos quais integrantes de partidos com pontos de vista opostos competem para controlar o poder legislativo e que as leis produzidas representam a prevalência, pelo menos por um período, de um ponto de vista sobre os demais. Em outras palavras, o autor não desconsidera o viés ideológico contido nas leis, mas ainda assim defende a sua autoridade. O que garante, então, que tal autoridade não será arbitrária? Qual a segurança que os cidadãos possuem, a partir da perspectiva positivista normativa, de que o direito produzido meramente segundo critérios formais não será injusto ou contrário aos clamores morais mais consolidados em uma sociedade? A resposta a estas questões demanda uma análise entrelaçada da teoria da democracia e da teoria do direito de Waldron.

a reduzir a desigualdade, a aumentar ou pelo menos manter o nível de prestações de bem-estar e regular negócios e indústrias no interesse da saúde e segurança no trabalho, igualdade sexual e racial, integridade ambiental e a promover o bem público." (WALDRON, 1993, p. 2).

${ }^{17}$ Pode-se dizer que Waldron se filia a uma teoria da democracia radical em razão de admitir que tudo deve estar aberto ao debate político, isto é, ele não se preocupa em retirar do debate um rol de direitos (os direitos fundamentais ) que comumente estão submetidos á quoruns qualificados de votação para serem modificados ou são até mesmo considerados cláusulas pétreas. Em sua teoria, todos os direitos devem ser suscetíveis de modificação por maioria simples em votações legislativas. Cf. WALDRON, 1999. vol. 08, nº. 04, Número Especial. Rio de Janeiro, 2015. pp. 2424-2448 
Em outras palavras, trata-se primeiramente de entender a justificação da autoridade da legislação para, em segundo lugar, verificar como essa autoridade se relaciona a uma teoria do direito que exige obediência à autoridade da lei aprovada segundo critérios formais e que deve manter a tese da separação entre direito e moral.

\section{Teoria da democracia, desacordos e autoridade do direito}

O melhor ponto de partida para análise da teoria da democracia de Waldron é a compreensão das "circunstâncias da política", conceito adaptado daquele de "circunstâncias da justiça" ${ }^{18}$ de John Rawls, segundo o qual em condições normais sob as quais a cooperação humana é possível e necessária, as regras sociais e legais criam certos direitos para estabilizar as relações humanas. Com base neste conceito, sustenta-se hodiernamente que as constituições devem abrigar três diferentes conjuntos de direitos relacionados à justiça (liberdade individual de pensamento, consciência e ação, propriedade, trabalho, família, entre outros); à consistência (devido processo legal e igualdade perante a lei); e à equidade (aqueles associados ao funcionamento da democracia, tais como a liberdade de expressão e associação, funcionamento do sistema eleitoral, etc). ${ }^{19}$

Embora esses direitos sejam relacionados e suportem-se mutuamente, pode haver tensão entre eles no momento de sua aplicação social, uma vez que sua natureza e significado podem ser objeto de divergências (por exemplo: direito à vida v. aborto; direito de propriedade v. bem-estar social; liberdade de expressão v. privacidade). Desse modo, embora os direitos sejam necessários em razão das "circunstâncias da justiça”, eles devem ser identificados e interpretados no que Waldron chama de "circunstâncias da política", ou seja, em circunstâncias nas quais é preciso chegar a um acordo coletivo e coercitivo sobre o caráter dos direitos, haja vista a existência de opiniões e interesses divergentes. (cf. WALDRON, 1999, p. 101/102). As circunstâncias da política, assim, são constituídas pela existência de desacordos políticos ou morais e pela necessidade de decisões com autoridade política para regular o desacordo. Desacordo e autoridade política passam a ser, desse modo, os principais conceitos a serem elucidados nesta seção.

Os desacordos são inerentes às sociedades contemporâneas, as quais são plurais em relação a concepções de justiça e de vida boa. De acordo com Waldron, a existência de desacordos não deve ser entendida como um sinal de crise no direito, pois é natural que o direito, diante das circunstâncias da política, "tenha pretensões que conflitem com o sentido de justiça de alguns ou de muitos dos que se encontram sob sua autoridade." (WALDRON, 1999, p. 7). Não obstante a naturalidade dos desacordos em sociedades plurais, o autor sustenta ser necessário a uma teoria do direito e, principalmente a uma teoria da autoridade, apontar quais os procedimentos democráticos e constitucionais são adequados em caso de desacordo entre teorias da justiça

\footnotetext{
${ }^{18}$ Para uma análise aprofundada desse conceito, ver RAWLS, 2008, p. 153ss.

${ }^{19}$ Essa apresentação e distinção dos conjuntos de direitos é tomada de Richard Bellamy. Cf. BELLAMY, 2007, p.18/19. vol. 08, nº. 04, Número Especial. Rio de Janeiro, 2015. pp. 2424-2448
} 
concorrentes. (cf. WALDRON, 1999, p. 3). Isso porque em seu entendimento a principal característica do direito em sociedades marcadas pelas circunstâncias da política é "permitir-nos agir diante do desacordo" (WALDRON, 1999, p. 7).

O desacordo inevitável e compatível com a política, contudo, parece ter um conteúdo normativo. Neste ponto, Waldron compartilha com os teóricos da democracia deliberativa que o desacordo viável para as práticas democráticas é o denominado desacordo razoável ou de boa fé. Argumentar de boa fé, explica ele, "é apresentar razões que (alguém pensa que) o outro deveria aceitar, e que duas ou mais pessoas persistam em seus argumentos lhes faz perceber e buscar a mesma possibilidade de que ao final as mesmas considerações serão capazes de convencer a todos." (WALDRON, 1999, p. 91).

Essa noção de desacordo razoável ou de boa fé tenta afastar da política a intolerância que, por sua vez, pode levar a decisões arbitrárias e desrespeitosas em relação aos direitos de minorias dissidentes. ${ }^{20}$ Entretanto, do fato de os participantes de um processo de decisão coletiva assumirem a perspectiva do desacordo razoável ou de boa fé não resulta, necessariamente, que chegarão a um consenso. ${ }^{21}$ No mundo real, esclarece o autor, "mesmo após a deliberação, as pessoas continuarão discordando de boa fé sobre o bem comum, sobre questões de política, de princípios, de justiça e de correção sobre as quais se espera que um Parlamento delibere." (WALDRON, 1999, p. 93) É exatamente em razão da impossibilidade de se eliminar o desacordo que surge a necessidade de uma teoria da autoridade. Na proposta de Waldron, a teoria da autoridade está estreitamente relacionada com a dignidade da legislação e com a defesa da decisão majoritária.

Ao analisar a questão da autoridade do direito relacionando-a com a questão do desacordo, Waldron acentua que lhe interessa investigar em que medida é significativo para a teoria do direito que os Parlamentos incorporem os desacordos em seus próprios procedimentos e, ainda, interessa-lhe, sobretudo, se isso é significativo para a autoridade do direito (cf. WALDRON, 1999, p. 24).

Ao buscar um fundamento convincente para a autoridade do direito, Waldron procura uma resposta capaz de afastar a arbitrariedade da legislação e, por conseguinte, do direito. Ele começa por reconhecer que o argumento da legitimidade democrática da legislação é insuficiente para explicar a própria autoridade da

\footnotetext{
${ }^{20}$ Um estudo sobre o papel do direito e do Estado diante da intolerância pode ser encontrado em um livro recente de Waldron, chamado The Harm in Hate Speech (cf. WALDRON, 2012). Nesse texto o autor defende a legitimidade de leis coibindo discursos de ódio por entender que se trata de uma manifestação de intolerância, que afeta a dignidade dos atingidos e prejudica o ambiente democrático salutar para as sociedades hodiernas. Nesse sentido, a intolerância ou a insistência em um desacordo não razoável é entendida como algo que tem o condão de colocar em risco as práticas democráticas de uma sociedade.

${ }^{21}$ Apesar de compartilhar a noção de desacordo razoável ou de boa fé com os teóricos da democracia deliberativa, Waldron tece críticas a muitos dos representantes dessas teorias. A crítica central é direcionada à busca do consenso como um resultado político. Em seu entendimento, o consenso pode ser aceito na lógica interna da deliberação, como algo que se busca alcançar. Mas não se pode considerar que no caso do consenso não ser alcançado o resultado da deliberação foi insatisfatório. $\mathrm{O}$ autor considera que o dissenso ou o desacordo tende a permanecer mesmo após a deliberação e a votação pautada na razoabilidade ou na boa fé. Cf. WALDRON, 1999, p. 91/92.
} 
legislação. Isso porque antes de se sustentar a legitimidade democrática é necessário avaliar o próprio papel desempenhado pela decisão majoritária e sua legitimidade. As leis adquirem autoridade jurídica após serem aprovadas pelo poder legislativo e sancionadas pelo poder executivo. Desse modo, o que thes garante autoridade é sua aprovação mediante decisão majoritária. Porém, em que medida a decisão majoritária não pode ser considerada arbitrária? Waldron problematiza esse procedimento do seguinte modo:

Mas a contagem de votos se parece mais com o lançamento de uma moeda ao ar do que ao exercício da razão e do intelecto que caracteriza a consagração de outras fontes do direito como, por exemplo, o desenvolvimento de uma nova doutrina, um princípio ou uma exceção nas deliberações de um tribunal. Como podemos esperar, então, que a legislação seja levada a sério quando para determiná-la recorremos a este método aparentemente arbitrário? (WALDRON, 1999, p. 89).22

Esse excerto, no qual o autor problematiza a decisão majoritária e questiona sua racionalidade, não reflete sua opinião a respeito da decisão majoritária, mas chama a atenção exatamente para a necessidade de racionalidade nos procedimentos que darão origem às leis. É preciso então fazer uma distinção entre processos de legislação arbitrários e processos de legislação razoáveis. A autoridade do direito está atrelada à razoabilidade do processo legislativo (razoabilidade no sentido de apresentação de razões que podem ser aceitas pelos demais participantes de um determinado processo de deliberação e votação). O processo legislativo deve ser razoável uma vez que "a razão é necessária tendo em vista os altos interesses de política, moralidade e justiça que estão em jogo" (WALDRON, 1999, p. 90).

A intenção de Waldron é apresentar a legislação de um modo mais positivo do que normalmente ela é apresentada na teoria do direito. Em seu entendimento, concede-se aos tribunais, principalmente na teoria constitucional, um tratamento mais generoso do que aquele oferecido aos Parlamentos. No direito constitucional contemporâneo, afirma ele, "a arbitrariedade da decisão majoritária no Parlamento é frequentemente citada como uma forma de fortalecer a legitimidade do controle de constitucionalidade das leis." (WALDRON, 1999, p. 90). Aqui o autor está a chamar a atenção para um ponto importante em seu argumento, o qual será retomado inúmeras vezes em seus textos, a saber: "quando os juízes de um tribunal discordam, eles também decidem mediante uma votação por decisão majoritária. A diferença entre o Parlamento e o tribunal consiste em quem elegeu seus membros e não no método de decisão utilizado." (WALDRON, 1999, p. 90/91). Sua conclusão a respeito dessa equiparação é bastante forte: "se o voto produz decisões arbitrárias, quase todo o direito constitucional é arbitrário." (WALDRON, 1999, p.90/91).

A questão que precisa ser respondida, assim, é: como apresentar a legislação como uma fonte de direito digna e responsável? Como afastar o argumento da arbitrariedade? A busca por uma resposta para essas questões leva Waldron a um diálogo com a teoria positivista do direito, especialmente com Raz, no intuito de averiguar os argumentos oferecidos para defender a autoridade do direito.

${ }^{22}$ Itálico acrescentado. 
Waldron reconhece que o direito positivo admite como direito uma disposição que tenha se tornado direito de modo arbitrário, isto é, sem nenhuma conexão com o conteúdo, a substância ou a qualidade da disposição. Em outras palavras, o direito positivo pode ser direito e ao mesmo tempo ser injusto. Nesse sentido, resta saber o que justifica a autoridade do direito.

A resposta dada por Raz para a autoridade do direito procura uma justificação distinta daquela oferecida acima. Segundo Waldron, Raz justifica a autoridade do direito do seguinte modo:

(...) o que permite reconhecer a uma pessoa ou a uma instituição A como autoridade em relação a uma determinada matéria $M$ é que fazemos melhor seguindo as diretrizes emitidas por $\mathrm{A}$, a respeito das razões pertinentes relativas a $\mathrm{M}$, do que tentando descobrir por nós mesmos o que deve ser feito sobre a matéria M. (WALDRON, 1999, p. 95/96)

Um exemplo de como funcionaria esse modelo de autoridade seria o seguinte: um cidadão poderia reconhecer que o Estado brasileiro é uma autoridade no que diz respeito ao controle de velocidade no trânsito desde que considerasse que estaria mais seguro no trânsito seguindo as leis do Estado brasileiro sobre os limites de velocidade em rodovias federais do que se tentasse descobrir, por si mesmo, qual a melhor velocidade para trafegar com segurança em cada localidade. ${ }^{23}$

No que diz respeito ao modo como Raz define a autoridade do direito, Waldron considera que o argumento apresentado atenua muito pouco o temor da arbitrariedade, seja porque não diferencia entre as normas emanadas de um soberano unitário e aquelas originárias de um processo de voto majoritário, seja porque não justifica porque o destinatário deve seguir a diretriz da norma e não seu próprio juízo. Waldron considera que deve haver algo na origem de determinada norma ou no procedimento pelo qual ela foi alcançada que proporcione aos cidadãos maior segurança ao tentar seguir a referida norma do que em tentar descobrir sozinhos o que se deve fazer a respeito da matéria regulada pelo direito (cf. WALDRON, 1999, p. 96). ${ }^{24}$

Assim, a questão da autoridade e do afastamento da arbitrariedade ainda permanece em aberto. Por que um cidadão deveria preferir o ponto de vista do poder legislativo ao seu próprio? Se a opinião com a qual o cidadão compartilha foi derrotada em uma decisão no Parlamento, por que ele deve conferir autoridade à opinião que prevaleceu? Na perspectiva waldroniana, a decisão majoritária exige o respeito dos cidadãos por se tratar de um processo de tomada de decisões que não tenta, mediante o uso de algum subterfúgio filosófico (como, por exemplo, o apelo a um legislador ideal ou a um juiz ideal como o Hércules de Dworkin) deixar de lado a pluralidade e os desacordos (cf. WALDRON, 1999, p. 99).

$\mathrm{Na}$ esteira desse pensamento, $\mathrm{o}$ autor sustenta que:

(...) a dignidade da legislação, o fundamento de sua autoridade e sua pretensão de respeito, tem a ver com o tipo de êxito que ela alcança. Nosso respeito pela legislação é em parte o

\footnotetext{
${ }^{23}$ Exemplo adaptado de Waldron. Ver WALDRON, 1999, p. 84.

${ }^{24}$ Waldron estabelece um interessante debate com a obra de Raz a respeito da autoridade do direito. Para uma análise mais aprofundada desse tema ver: WALDRON, 1999, capítulos IV, V e VI.
} 
tributo que devemos pagar pelo êxito da ação coletiva acordada, cooperativa e coordenada nas circunstâncias da vida moderna. (WALDRON, 1999, p. 101)

Nessa perspectiva, a decisão majoritária não pode ser considerada, a priori, como uma decisão arbitrária simplesmente pelo fato de ser uma agregação de preferências. Embora a decisão majoritária seja um procedimento técnico, Waldron defende que pode ser também um método moralmente respeitável. $\mathrm{O}$ autor procura afastar algumas críticas tecidas à decisão majoritária, tais como aquela que a considera um princípio impessoal, puramente agregativo e que não leva os indivíduos suficientemente a sério. Segundo ele, há pelo menos dois aspectos em que a decisão majoritária respeita os indivíduos cujo voto é agregado, a saber:

Em primeiro lugar, respeita suas diferenças de opinião sobre a justiça e o bem comum: não exige que ninguém desista de um ponto de vista que sustenta sinceramente ou que ele seja silenciado por causa da importância imaginária do consenso. Em segundo lugar, incorpora um princípio de respeito a toda pessoa no processo pelo qual se decide sobre uma concepção que deve ser adotada como a nossa, mesmo diante dos desacordos. (WALDRON, 1999, p. 109) 25

Ademais, a autoridade de uma lei aprovada pelo Parlamento reside não apenas no respeito aos desacordos, mas também nos procedimentos que regulam sua aprovação. A autoridade, ressalta o autor, "requer uma perícia superior, e esta provém da deliberação entre pessoas diferentes entre si." (WALDRON, 1999, p. 85). A deliberação, porém, deve ser regulada por regras formais e procedimentos que permitam a discussão. Isso implica, é claro, uma concepção de representação política que permita ao Parlamento se configurar como um espaço adequado para a manifestação dos desacordos, isto é, que seja um local no qual a diversidade esteja equitativamente representada, que permita às vozes em contenda serem escutadas em um debate regulado por procedimentos respeitosos com os desacordos.

O respeito aos desacordos, por sua vez, deve levar a sério a noção de desacordo razoável ou de boa fé, evitando-se a negação do ponto de vista alheio como baseado no auto-interesse ou em uma observação insuficiente da realidade moral. Esse é um ponto delicado que poderia aproximar a proposta de Waldron do relativismo moral. $\mathrm{O}$ autor, entretanto, refuta essa aproximação ao afirmar que o tipo de respeito que busca para os diferentes pontos de vista "não implica a rejeição da premissa sobre a singularidade da verdade, isto é, não implica necessariamente algo como o relativismo." (WALDRON, 1999, p. 111). Ele reconhece que o fato do desacordo não pode levar à conclusão de que não existem respostas corretas, pois certamente entre diversas concepções de justiça concorrentes algumas serão mais aceitáveis do que outras.

A questão epistemológica por trás dessa discussão a respeito da existência ou inexistência de objetividade moral ou de uma verdade é que, na concepção de Waldron, esse é um ponto irrelevante. Ainda que se admita a existência de objetividade moral, assim como a possibilidade de um legislador ou de um juiz identificá-la, isso

\footnotetext{
${ }^{25} \mathrm{O}$ itálico consta no original. Waldron dialoga com a teoria da escolha social, notadamente com Condorcet e com Kenneth Arrow e suas críticas à decisão majoritária. Não cabe aqui reproduzir esse debate, mas uma análise mais aprofundada pode ser encontrada em WALDRON, 1999, Caps. II, III, V e VI.
} 
pouco contribuiria para a resolução dos desacordos, haja vista que dificilmente as partes envolvidas admitiriam que o ponto de vista do legislador ou do juiz a respeito de uma determinada concepção de justiça ou de moralidade é mais adequado do que o seu. (cf. WALDRON, 1999, p. 195ss; STACEY, 2010, p. 753)

Por essa razão, o direito não deve estar associado apenas à tentativa de alcançar essa verdade moral, mas deve preocupar-se principalmente em assegurar o respeito às diversas concepções morais que coexistem na sociedade e, principalmente, precisa buscar a realização dessa tarefa eliminando a arbitrariedade. $\mathrm{O}$ posicionamento do autor sobre objetividade moral e desacordos é bastante claro no excerto abaixo:

O respeito tem a ver com o modo como tratamos as crenças uns dos outros sobre a justiça em circunstâncias nas quais nenhuma delas é autojustificatória, e não sobre como consideramos a verdade sobre a justiça mesma (....). Trata-se, em vez disso, que seja qual for o estado de minha confiança sobre a correção da minha própria concepção, preciso compreender que a política existe, nas palavras de Arendt, porque 'a terra não está habitada por um só homem, mas por homens, que compartilham o mundo entre eles' - não uma única pessoa, mas um povo - que a minha não é a única mente trabalhando no problema diante de nós, que há inúmeras inteligências distintas e pensar que pessoas razoáveis discordarão não é inesperado, não natural ou irracional. (WALDRON, 1999, p. 111/112)

Nesse contexto, marcado por desacordos razoáveis, a autoridade da legislação, e do direito por conseguinte, é defendida por Waldron com base em dois argumentos: o argumento da equidade e o argumento da razoabilidade. Ambos são invocados no intuito de afastar a arbitrariedade de uma lei aprovada por decisão majoritária.

A decisão majoritária pode ser considerada equitativa em razão de conferir igual peso ao ponto de vista de cada pessoa envolvida no processo de decisão (ou pelo menos, igual peso ao voto de cada representante). Nesse sentido, assume-se que uma determinada questão sob deliberação é controversa, mas assume-se também que as opiniões em desacordo são razoáveis e que o resultado da votação, portanto, é merecedor de respeito porque foi alcançado segundo procedimentos equitativos e que levaram em consideração os pontos de vista divergentes.

A decisao majoritária também é razoável exatamente em razão das circunstâncias da política. Para Waldron, "cada característica do método de decisão majoritária que pareça arbitrária pode ser defendida como razoável nas circunstâncias da política, e de fato como expressiva do que talvez seja a concepção de respeito pelas pessoas mais robusta que temos o direito de esperar nessas circunstâncias". (WALDRON, 1999, p. 116). Um exemplo trazido pelo autor é bastante esclarecedor a respeito da relação entre autoridade e decisão majoritária em contextos de desacordo:

Uma pessoa que possui uma completa teoria política - que inclui uma teoria da autoridade tanto quanto teorias da justiça, dos direitos e da políica - pode encontrar a si mesma comprometida com uma visão de que a decisão errada pode prevalecer. Sua teoria da justiça pode desaprovar a política B e preferir a política A baseada em direitos, mas sua teoria da autoridade pode apoiar um procedimento de decisão (desenhado para produzir uma 
escolha social em face do desacordo sobre, por exemplo, a justiça de A ou B) que, quando seguida, requer que B seja implementada. (WALDRON, 1999, p. 246)

Para o autor essa é uma situação natural e não contraditória, haja vista que a pessoa do exemplo está oferecendo, na realidade, respostas para duas questões diferentes, embora complementares. Desse modo, "[q]ue B deveria ser implementado é sua resposta para a questão 'O que devemos fazer dado que discordamos sobre se $\mathrm{A}$ ou B é justo?' Que A é a decisão correta é sua própria contribuição ao desacordo que suscitou essa questão." (WALDRON, 1999, 247/248).

Desse modo, na concepção de Waldron, a autoridade da lei:

Reside em seu surgimento, de acordo com procedimentos específicos, como um unum que surge de uma pluralidade de ideias, preocupações e propostas, em circunstâncias em que reconhecemos a necessidade de uma decisão tomada conjuntamente e não de muitas decisões tomadas por cada um de nós sozinhos. O unum não suprime a pluralidade, nem é insensivel a ela. (...) A decisão é tomada em nome, e para o bem, de toda a comunidade, e espera-se que tenha sido tomada de modo que encoraje ao invés de impedir uma pluralidade de contribuições de distintas perspectivas. A decisão que tomamos é o texto de uma lei determinada pelos procedimentos da instituição. Esses procedimentos nos fazem um para a ação e a identificação de algo como o texto de uma lei nos faz um como autores de uma obra. Antes e depois deste ponto, entretanto, somos muitos e nenhuma outra condição de parte do unum pode ser atribuída para qualquer outra coisa que qualquer um de nós diga ou pense. (WALDRON, 1999, p. 144/145) ${ }^{26}$

A autoridade do direito, assim, reside em sua origem de acordo com procedimentos capazes de incorporar e respeitar os desacordos. A validade do direito está atrelada à observância de tais procedimentos e, como visto, não pode se respaldar em uma concepção de justiça e/ou moralidade exatamente porque, segundo Waldron, essas são concepções que estão imersas nas circunstâncias da política e são objeto de desacordos.

Essa definição da autoridade do direito tem implicações importantes não apenas para a validade, mas também para a interpretação do direito, levando Waldron a refutar as propostas de interpretação da lei que levam em consideração as intenções do legislador. Se a autoridade da lei deriva exatamente do fato de ter sido aprovada de acordo com um conjunto de procedimentos que levam em consideração os desacordos, recorrer à intenção do legislador, como, por exemplo, a debates e posicionamentos que foram vencidos na votação final, é, na concepção de Waldron, justamente desrespeitar a opinião ou o ponto de vista que foi vitorioso de acordo com a decisão majoritária.

Nesse sentido, em defesa da estabilidade política e da segurança jurídica, Waldron ressalta que a lei aprovada segundo a decisão majoritária não pode ser entendida como um ato de vitória de uma facção sobre outra. Em suas palavras: "[u]ma lei aprovada pelo Parlamento é uma Lei do Parlamento e não um ato do partido majoritário. Certamente, ela afirma sua autoridade na comunidade sobre a base desta caracterização não partidária” (WALDRON, 1999, p. 144). As minorias e os dissidentes devem respeito a uma lei com a qual

\footnotetext{
${ }^{26}$ As palavras em latim e o itálico constam no original.
} 
discordam porque ela foi aprovada pelo Parlamento, segundo os procedimentos e formas institucionais que o regulam, e não porque se trata da decisão da maioria enquanto tal.

Estabelece-se, assim, um compromisso, seja da parte dos cidadãos, seja da parte dos intérpretes, de que a autoridade da lei deve ser respeitada. Ainda que não se concorde com o conteúdo de uma determinada norma, a solução apontada pelo autor não é ignorá-la ou tentar modificá-la no momento de sua aplicação, mas sim trabalhar com responsabilidade pela sua revogação. (cf. WALDRON, 1999, p. 100). Por essa razão, Waldron considera que qualquer discurso sobre as intenções do legislador deve ser abandonado no momento da interpretação da norma, haja vista que a autoridade da lei reside no texto aprovado, que é aquele que finalmente foi o resultado da decisão dos legisladores. ${ }^{27}$

Exatamente em razão de conferir grande credibilidade à dignidade da legislação, por considerar que a legislação é fruto do trabalho de um Parlamento representativo e cujos procedimentos de deliberação e de votação podem apresentar a melhor resposta para o desacordo político, é que Waldron busca entrelaçar a teoria da democracia e a teoria do direito. A autoridade do direito está atrelada exatamente à adequação dos procedimentos políticos para lidar com os desacordos morais, políticos e sobre justiça. A validade do direito, portanto, não pode vincular-se a um conteúdo (moral, político ou de justiça) em razão do próprio desacordo a respeito desses conteúdos. A interpretação do direito, por sua vez, deve restringir-se à textualidade da lei aprovada. Isso porque, na concepção de Waldron, o fórum mais adequado para a resolução dos desacordos é o político e não o jurídico. E essa é a premissa que liga sua teoria da democracia à sua teoria do direito e à perspectiva do positivismo jurídico normativo.

\section{Teoria do direito e o positivismo jurídico normativo}

Na seção anterior foram apresentadas as bases sobre as quais se assenta a teoria do direito de Waldron. Trata-se de uma teoria delineada no intuito de vincular valores democráticos à teoria do direito, enfrentando questões complexas como a justificação da autoridade do direito em sociedades nas quais se torna cada vez mais difícil falar em verdade ou objetividade moral. Aqui, buscar-se-á mostrar como a teoria da democracia e da autoridade apresentadas anteriormente se conectam com uma teoria do direito na versão do positivismo normativo.

A análise da teoria do positivismo jurídico normativo de Waldron será feita em dois momentos. Primeiramente, será abordado o aspecto metodológico da teoria e a discussão em torno da possibilidade de uma

\footnotetext{
${ }^{27}$ Waldron tem se destacado como um dos grandes críticos do ativismo judicial e também do controle de constitucionalidade das leis. Não se aprofundará neste texto a discussão do autor em torno de questões de interpretação e aplicação de normas jurídicas. Entre os textos de Waldron que tratam desse tema, ver: WALDRON, 2006, p. 1346-1406; WALDRON, 2009, p. 267-282; WALDRON, 2010, p. 1043-1057.
} 
teoria do direito não meramente descritiva. Em um segundo momento, serão apresentadas algumas características que o autor considera como distintivas do positivismo jurídico e, especificamente, da perspectiva do positivismo jurídico por ele defendida.

Assim, o primeiro aspecto a ser analisado é o metodológico. No que diz respeito à metodologia, há, no âmbito da teoria do direito, uma discussão a respeito de se a ciência do direito é essencialmente descritiva ou se ela pode também ser normativa ou prescritiva. A aceitação de um viés normativo na teoria do direito, já presente nas obras de alguns autores não positivistas como John Finnis e Ronald Dworkin, se encontra atualmente também dentro do próprio positivismo jurídico, que em versões anteriores, como naquelas de Kelsen e de Hart, concebiam a teoria do direito como essencialmente descritiva (cf. WALDRON, 2008, p. 681).

De acordo com Waldron, o positivismo jurídico é uma concepção do direito que pode ser tanto descritiva quanto prescritiva ou normativa. O positivismo jurídico descritivo é uma visão a respeito do que as decisões jurídicas implicam. Já o positivismo jurídico normativo ${ }^{28}$ é uma visão a respeito do que as decisões jurídicas devem implicar. Historicamente, o positivismo jurídico normativo remonta às teses de Thomas Hobbes e de Jeremy Bentham, os quais não estavam preocupados com a separação entre direito, justiça e moral apenas com objetivos teóricos ou conceituais. De modo distinto, tais autores estavam interessados "nas condições necessárias para a coordenação e resolução de conflitos e para a estabilidade geral das expectativas das relações das pessoas entre si." (WALDRON, 2001, p. 413).

Ambas as concepções sustentam que "o direito deve ser entendido em termos de regras ou padrões cujo status jurídico deriva de alguma fonte humana definida sociologicamente." (WALDRON, 1999, p. 166). Portanto, ambas as concepções associam a validade do direito à sua origem em algum fato social (legislação ou decisão judicial) que pode, é claro, incorporar juízos morais. Mas uma vez criada a norma jurídica ela independe de qualquer juízo moral para sua identificação, interpretação ou aplicação.

A tese central do positivismo jurídico descritivo é que cabe ao intérprete e ao cientista do direito apenas descrever aquilo que é o direito em um determinado tempo e lugar. As lacunas ou indeterminações que eventualmente venham a surgir são compreendidas como a inexistência de direito regulando determinados casos, os quais podem então ser resolvidos mediante uma decisão política, que não deve ser entendida, obviamente, como uma decisão jurídica com caráter político ou moral. A concepção descritiva do positivismo jurídico é neutra

\footnotetext{
${ }^{28}$ Waldron ressalta que a versão do positivismo normativo por ele defendida não pode ser confundida com o que às vezes também é chamado, a partir do positivismo de Kelsen ou de Hart, de positivismo normativo. Na proposta de Kelsen e de Hart o termo "normativo" é utilizado apenas para identificar o direito com normas jurídicas (em sentido oposto ao poder, ao comando e às sanções como um fato), mas a metodologia permanece descritiva. Waldron ressalta que essa versão normativa ou prescritiva do positivismo jurídico tem sido chamada também de positivismo ético, como na obra de Tom Campbell. O termo "positivismo ético" também é recusado por Waldron em razão de sua possível ênfase em uma teoria normativa mais focada em padrões de comportamento individual do que institucional. Cf. WALDRON, 2001, p. 411/412.
} 
em relação à natureza dos juízos morais, pois considera que decisões jurídicas estão desconectadas de juízos morais.

Waldron critica a postura meramente descritiva do positivismo jurídico por não conseguir fazer valer sua tese na prática, haja vista sempre haver uma demanda interpretativa que fará com que se recorra a um juízo moral. Por outro lado, em seu entendimento o positivismo normativo lidaria melhor com essas questões ao sustentar a tese segundo a qual:

(...) o direito deve ser tal que as decisões jurídicas possam ser tomadas sem a intervenção de juízos morais. Ou, se não quisermos usar a linguagem da obrigação: é a tese de que seria desejável para o direito ser aquilo que os positivistas descritivos creem que ele é. $\mathrm{O}$ positivismo normativo é, em si mesmo, uma pretensão moral: de fato, é uma interpretação moral acerca da formulação de outras pretensões morais no âmbito específico da vida social que chamamos direito, e identifica a contaminação das decisões jurídicas pelos juízos morais como uma desvantagem moral; que perdemos algo valioso desse modo. Trata-se claramente de uma versão mais interessante do positivismo jurídico, e de fato é difícil imaginar como uma definição positivista do conceito de direito poderia ser defendida sem apelar eventualmente a alguma tese normativa como esta. (WALDRON, 1999, p. 167). ${ }^{29}$

$\mathrm{O}$ autor ressalta que as diferenças entre as duas formas de compreensão do positivismo têm implicações práticas com relação aos casos que podem demandar uma decisão moral no direito. Enquanto na concepção descritiva "tais casos são ameaças ou contraexemplos que devem ser reconceituados ou aos quais devemos dar alguma explicação se queremos manter a tese descritiva," na versão normativa do positivismo defende-se que casos que podem demandar decisões morais "são elementos insatisfatórios do direito que devem ser censurados ou minimizados" e, para alcançar esse resultado, "o sistema jurídico deveria ser reformado para que tais decisões morais, tomadas por juízes ou funcionários públicos, fossem erradicadas na medida do possível." (WALDRON, 1999, p. 167).

Aqui se sobressai novamente a preocupação de Waldron com a eliminação dos aspectos arbitrários do direito. A arbitrariedade, segundo definições da filosofia do direito contemporânea, pode ser entendida em três sentidos: como imprevisibilidade de uma decisão, como irracionalidade da decisão e, por fim, como ausência de legitimidade política ou democrática. Segundo Waldron, sempre que é permitido a um juiz ou a um funcionário não eleito tomar decisões morais os cidadãos são colocados, em alguma medida, diante da arbitrariedade em um dos sentidos acima mencionados.

A metodologia proposta pelo positivismo jurídico normativo não é isenta de críticas. Waldron enfrenta algumas delas em Normative (or Ethical) Positivism. Não se pretende aqui reconstruir toda a argumentação do autor, mas apenas enfatizar alguns pontos considerados relevantes no âmbito metodológico. Nesse aspecto, os pontos que serão analisados a seguir são fruto de um debate entre Waldron e Jules Coleman, autor vinculado à perspectiva positivista inclusiva. As principais críticas formuladas por Coleman são as seguintes: primeiramente,

\footnotetext{
${ }^{29}$ Itálico no original.
} 
ele acusa o positivismo normativo de não ser uma versão do positivismo jurídico, mas simplesmente uma tese a respeito do positivismo jurídico, haja vista o positivismo normativo assentar-se sobre a (principal) tese conceitual do positivismo jurídico, a saber, a separação entre o direito e a moral. A segunda crítica consiste na alegação de que ao adotar uma versão normativa do positivismo jurídico, acaba-se por infundir a moralidade no conceito de direito, isto é, acaba-se por determinar aquilo que o direito deve ser e, nesse sentido, o positivismo normativo faria ruir a tese da separação, tornando até mesmo difícil distinguir a posição normativa do positivismo da teoria do direito natural, segundo a qual uma concepção moral pode exercer influência sobre o direito positivo. (cf. WALDRON, 2001, p. 413-418)

Em resposta à primeira crítica, Waldron afirma que a assunção principal do positivismo normativo é que "os valores associados ao direito, à legalidade e ao Estado de Direito (...) podem ser melhor alcançados se a operação ordinária de tal sistema não requer do povo o exercício de julgamento moral a fim de descobrir o que o direito é."(WALDRON, 2001, p. 421) Essa tese central não requer, afirma o autor, "qualquer etapa puramente descritiva, conceitual ou não normativa." (WALDRON, 2001, p. 421). O argumento é, pois, sempre normativo.

A segunda crítica é refutada em parte, haja vista Waldron reconhecer que de fato há, na perspectiva normativa, uma pretensão moral a respeito do que o direito deve ser. Mas, segundo ele, os julgamentos particulares a respeito do que o direito é podem ser, em certa medida, isolados de julgamentos gerais a respeito da questão do direito. Contudo, esse isolamento nunca será completo, pois

(...) podem existir práticas ou arranjos políticos que, do ponto de vista normativo (o ponto de vista que descreve a função do direito) sejam piores do que nenhuma lei; e para esses casos o enfoque normativo geral pode afetar o enfoque normativo particular se (...) essas práticas ou arranjos devem ser considerados como leis. Mas esses serão casos extremos: de fato, serão exatamente aqueles casos para os quais de todo modo é mais difícil defender a insistência radical de que é possível determinar se algo é um direito sem fazer um julgamento sobre sua justiça ou sobre seu caráter moral (WALDRON, 2001, p. 418)

Dessa interferência da moral no direito não se pode inferir, segundo Waldron, que não há diferenças entre a proposta do positivismo normativo e aquela do jusnaturalismo. A principal diferença, ressalta o autor, consiste em que "o positivismo normativo não precisa se comprometer com qualquer metaética especial, nem com qualquer enfoque especial de como chegamos a uma compreensão do bem ou dos valores que o direito fornece." Ao contrário, a teoria do direito natural "é usualmente embalada com uma metaética distintiva (cognitivismo ou objetivismo) e frequentemente também com um forte compromisso com o enfoque racionalista da compreensão moral ou ética." (WALDRON, 2001, p. 418). Em um texto de 1996, denominado Kant's Legal Positivism, Waldron já havia tentado esclarecer esse ponto do seguinte modo:

[p]recisamos distinguir, entretanto, entre: primeiro, juízos de valor que podem ser requeridos em uma teoria do direito não positivista para identificar alguma proposição como uma norma legal válida; e segundo, juízos de valor que suportam a posição positivista de que avaliações do primeiro tipo não são necessárias. (WALDRON, 1996, p. 1541). 
A distinção é sutil, mas quando o positivismo jurídico normativo assume a interferência da moral no direito ele não está se referindo ao conteúdo de normas particulares, como faziam os jusnaturalistas, mas ao próprio sistema jurídico e ao modo como esse deve estar organizado de modo a atender aos clamores de uma sociedade livre e democrática. Nesse sentido, o positivismo normativo não se limita a ser uma teoria cuja preocupação repousa apenas sobre aspectos técnicos da teoria do direito, mas sua atenção volta-se também para a importância moral, social e política da distinção entre formas de governo que serão reguladas pelo direito. Trata-se exatamente de reconhecer não apenas que é melhor viver sob a égide do direito do que viver sem sua mediação, mas que o próprio direito é uma instituição desejável. Nas palavras do autor:

Mais impressionante para mim é a sugestão implícita de que a fim de fazer teoria do direito
do modo normativo deve-se entender o direito como uma coisa boa. Eu pareço ter
argumentado na posição de dizer que, ainda que um positivista deseje negar a justiça ou a
virtude de leis particulares, ele tem que organizar sua teoria do direito em torno da ideia de
que o direito como tal é uma instituição desejável; de outro modo (pareço estar dizendo) a
metodologia de sua teoria do direito é estéril e meramente semântica. (WALDRON, 2001,
p. 428)

Assim, no que diz respeito à metodologia, o positivismo normativo defende uma concepção normativa ou prescritiva do direito, abandonando a pretensão meramente descritiva do direito enquanto tal. Nesse sentido, trata-se de uma concepção moral e também política a respeito do que o direito deve ser, a qual estipula justamente que considerações morais não devem ser admitidas na determinação do direito, uma vez que fazer o direito depender de critérios e argumentos morais implicaria atentar contra a dignidade e a autoridade da legislação aprovada num contexto de desacordos morais e políticos.

O segundo aspecto do positivismo normativo de Waldron que se pretende analisar é sua ênfase em algumas características distintivas do positivismo jurídico que podem aproximar sobremaneira esta teoria dos valores democráticos. Em um texto publicado em 2008, denominado Can there be a democratic jurisprudence?, Waldron revisita algumas das principais características do positivismo jurídico no intuito de delinear uma teoria do direito democrática. A partir de uma abordagem teórica e histórica, o autor ressalta que o positivismo jurídico possui algumas características distintivas, são elas: (a) a preocupação institucional com a fonte do direito, (b) a ênfase em uma regra de reconhecimento de normas; (c) a tese da separação entre direito e moralidade. A essas bem conhecidas características da teoria positivista Waldron acrescenta mais duas que considera terem permanecido sem a devida atenção, sobretudo no positivismo do século XX, quais sejam: (d) a publicidade (caráter público do direito) e, (e) a generalidade. (cf. WALDRON, 2008, p. 683/684) Essas características, que serão apresentadas a seguir, podem ser entendidas como o próprio conteúdo normativo da teoria positivista de Waldron.

1) A ênfase do positivismo nas fontes do direito justifica-se, segundo Waldron, seja porque a fonte funciona como uma alternativa para o enfoque baseado no conteúdo do direito (como no jusnaturalismo), seja em 
razão da eficácia, pois uma norma que provém de um sistema jurídico estatal tem mais chance de ser observada, ainda que mediante o uso da força, seja, por fim, em razão da legitimidade política. Esse último motivo é o que mais interessa a uma teoria do direito democrática. No que diz respeito à legitimidade política do direito, torna-se relevante responder quem, quais instituições e mediante quais procedimentos uma determinada norma foi criada. Na proposta do autor, como já assinalado no estudo de sua teoria da democracia, a resposta para quem deve participar das decisões que dão origem a leis é: todos que são governados por uma dada norma têm o direito de participar em iguais termos em sua determinação (p. 688). Quanto às instituições, elas devem ser representativas e manter procedimentos que permitam a participação equitativa e o respeito aos desacordos. (cf. WALDRON, 2008, p. 684-691).

2) No que tange à regra de reconhecimento como uma das principais características do positivismo jurídico, a discussão trazida por Waldron é basicamente a respeito de a quem a regra de reconhecimento é direcionada. Partindo da teoria de Hart, o autor observa que na teoria do direito contemporânea o reconhecimento do direito é concebido como uma tarefa para oficiais (juízes, legisladores, autoridades) e isso, de certo modo, compromete o aspecto democrático do próprio sistema. A crítica de Waldron a Hart é que ao admitir que basta para o sistema jurídico a existência de uma aceitação oficial compartilhada da regra de reconhecimento contendo o critério de validade do sistema, abre-se espaço para a opressão, pois uma grande parcela dos cidadãos não terá conhecimento da estrutura geral e dos critérios de validade do direito. Desse modo, "a especialização da autoridade normativa - implícita na ideia de regras secundárias - pode assim exacerbar qualquer exploração e hierarquia que existam em uma dada sociedade para além de sua legalização. E isso pode muito bem tornar possível certas formas de opressão" (WALDRON, 2008, p. 696). Na perspectiva de uma teoria do direito democrática, o próprio conceito de democracia não pode ser entendido apenas a partir dos procedimentos de eleição e participação, mas também está relacionado "ao direito sendo considerado, em sentido forte, como propriedade daqueles que são governados por ele" e, nesse sentido, "o direito democrático é o direito do povo e como tal seu caráter democrático é solapado pela ignorância do povo ou mistificação com relação às condições de sua produção." (WALDRON, 2008, p. 696). Realiza-se, assim, uma reavaliação da regra de reconhecimento apontando-se para a necessidade de a teoria do direito ser delineada de modo a estabelecer critérios claros sobre o funcionamento do sistema jurídico para que as leis possam ser reconhecidas e identificadas não apenas por autoridades, mas também pelo povo.

3) Sobre a tese da separação entre direito e moral já se discorreu bastante anteriormente tanto na análise da teoria da democracia quanto no exame das questões metodológicas. Cabe aqui apresentar apenas aquilo que Waldron considera a versão democrática da tese da separação. Sua defesa da separação entre direito e moral assenta-se em duas razões. A primeira razão é que a tese da separação entre direito e moral coaduna-se com 
uma teoria democrática do direito justamente porque há um grande desconforto, para aqueles que defendem os valores democráticos, com critérios baseados em conteúdo que recusam reconhecer como direito aquilo que o poder legislativo democrático aprovou num contexto de conflito a respeito do que deve ser considerado justo ou moral. Assim, diz Waldron, "nós democratas insistimos, como parte de nossa lealdade à democracia, que qualquer preconceito baseado em conteúdo deve ser deixado de lado a fim de permitir às pessoas escolherem livremente como seu direito quaisquer normas que elas pensam ser apropriadas." (WALDRON, 2008, p. 698). ${ }^{30}$ A segunda razão é o fato do desacordo moral, que reflete conflitos na política ordinária a respeito do que é justo ou moralmente correto. Esses desacordos devem ser resolvidos democraticamente por meio de votações segundo procedimentos pré-estabelecidos e não se recorrendo a um determinado conteúdo a respeito da justiça ou da moralidade. A versão democrática da tese da separação consiste exatamente em "separar a proposição que uma dada norma foi aprovada do modo correto da proposição de que ela era a norma correta a ser aprovada." (WALDRON, 2008, p. 700)

4) O caráter público do direito, ou a publicidade ${ }^{31}$, é uma característica essencial apontada por praticamente todas as teorias do direito e notadamente pelas teorias republicanas, sejam elas democráticas ou não. Ao invocar essa característica, Waldron procura tornar um pouco mais específico esse conceito bastante abstrato de caráter público ou de bem público. Atribuir conteúdo a essa noção geral de bem público, contudo, não é algo desejável na perspectiva positivista do direito, justamente porque se corre o risco de negar a tese da separação entre direito e moral, principalmente quando a própria noção do que é o bem público também está aberta ao desacordo. Esse é um grande ponto de divergência entre as teorias do direito, pois ou os critérios de validade e de reconhecimento de normas jurídicas fazem referência ao seu conteúdo (moralidade, justiça, bem comum, entre outros) ou recorrem a aspectos meramente formais e estruturais relacionados à sua produção, tais como eficácia, sistematicidade, etc. Diante desse impasse, o caminho trilhado por Waldron está mais vinculado à forma do que ao conteúdo, mas, sem abdicar da tese da separação, o autor vai um pouco

\footnotetext{
${ }^{30}$ Itálico no original.

${ }^{31}$ Em uma teoria que confere amplo suporte às práticas democráticas, como aquela de Waldron, a atribuição de um cuidado especial à questão da publicidade é extremamente relevante, sobretudo para afastar o argumento sempre presente nos debates em torno de teorias da democracia, da possibilidade de tirania da maioria, do autoritarismo ou do uso da democracia em sua versão majoritária para suprimir direitos das minorias. Um interessante relato histórico envolvendo a questão da publicidade (e de sua ausência) é feito por Hannah Arendt em seu clássico "Origens do Totalitarismo". Arendt ressalta que o poder totalitário estava completamente atrelado ao segredo, à falta de publicidade das metas a serem alcançadas pelo regime. Nesse sentido, é interess ante um relato trazido em uma nota de rodapé, na qual se lê o seguinte: "A esse respeito, há um relatório muito interessante, datado de 16 de julho de 1940, sobre uma discussão no quartel-general do Führer na presença de Rosenberg, Lammers e Keitel, a que Hitler deu início declarando os seguintes 'princípios básicos': 'Era essencial então não exibir nosso objetivo ulterior aos olhos de todo o mundo; (...) Portanto, não deve ficar óbvio que os decretos que mantenham ordem nos territórios ocupados levem à solução final [dos judeus]. Todas as medidas necessárias - execuções, transferência de população etc. - podem ser e serão executadas apesar da letra dos decretos."'(ARENDT, 1989, p. 392, nota 5). Esse excerto mostra que, mesmo em um regime já dominado pela força e pela propaganda totalitária, temia-se os resultados de dar publicidade às medidas extremas de violação de direitos que estavam por ser adotadas. $\mathrm{O}$ argumento que se levanta aqui é exatamente o da possibilidade de, quando submetida ao debate e ao crivo do interesse público, uma medida restritiva de direitos não conseguir apoio suficiente para sua aprovação.
} 
além do que um positivista tradicional admitiria. Segundo ele, "ao invés de dizer que nada é lei a menos que promova o bem público, podemos querer dizer que nada é lei a menos que pretenda promover o bem público, isto é, a menos que se apresente como orientada nesta direção." (WALDRON, 2008, p. 702) ${ }^{32}$ Assim, o caráter público do direito deve estar associado a duas características principais, a saber:

a) as normas devem pretender ser colocadas para toda a sociedade e,

b) as normas devem versar sobre matérias de interesses da sociedade como tal, e não apenas sobre matérias de interesse pessoal ou grupal dos envolvidos em sua formulação.

Para o autor, os positivistas contemporâneos não prestam a atenção devida ao caráter público da lei, notadamente, ao fato de que a lei apresenta-se não somente como um conjunto de comandos emitidos por uma autoridade competente e reconhecidos por uma elite, "mas também como um conjunto de normas feitas publicamente e emitidas em nome do público, normas que as pessoas comuns podem em algum sentido apropriar-se, enquanto membros do público." (WALDRON, 2008, p. 684) Isso não significa, é claro, a defesa de que a lei esteja de acordo com uma concepção de bem público, mas sim que para ser aceita como vinculante por pessoas que discordam sobre o significado do bem público a norma precisa estar orientada nessa direção. (cf. STACEY, 2010, p. 763)

5) Assim como ocorre com a publicidade, Waldron considera que a generalidade também é uma característica do direito pouco explorada na teoria positivista. A generalidade possui, para a teoria do direito, três aspectos relevantes: primeiramente, enfatiza-se o aspecto público da lei que é aplicada igualmente a cada membro da comunidade; em segundo lugar, cria uma estrutura de regras previsíveis de acordo com as quais as pessoas, na condição de agentes racionais, podem organizar suas vidas, suas metas e objetivos; em terceiro lugar, a lei aplica-se genericamente a cada um porque é promulgada em nome de toda a comunidade. O maior interesse de Waldron recai exatamente sobre a relação da generalidade com a igualdade de status dos cidadãos. A noção de generalidade abarca a ideia de tratamento equitativo pelo direito, haja vista estar implícito na ideia de generalidade da norma que todos serão considerados do mesmo modo e que não haverá discriminações, exceto se previsto em norma geral. Entendida deste modo, a generalidade é uma característica bastante significante para uma teoria do direito democrática. (cf. WALDRON, p. 707/708).

Ao analisar estas características do positivismo jurídico, Waldron acaba por colocar ênfase em alguns aspectos não ressaltados pelos positivistas contemporâneos, os quais aproximam a teoria positivista de uma teoria democrática do direito. De modo geral, a normatividade da perspectiva positivista defendida por Waldron incide não sobre o conteúdo do direito, mas sobre sua forma, isto é, sobre quais devem ser as fontes do direito, quais devem ser os critérios de reconhecimento, como o direito não deve depender de critérios morais e que o direito

\footnotetext{
${ }^{32}$ Itálico no original.
} 
deve possuir um caráter público e geral. A forma, contudo, acaba por interferir no conteúdo, buscando impedir a arbitrariedade na elaboração, na interpretação e na aplicação do direito.

\section{CONSIDERAÇÕES FINAIS}

Neste texto apresentou-se uma das principais tendências no debate do positivismo jurídico contemporâneo, a saber, o positivismo jurídico normativo. Essa perspectiva foi examinada a partir da teoria de Jeremy Waldron, filósofo e teórico do direito que tem concentrado esforços na elaboração de uma teoria do direito democrática.

Na primeira seção, no intuito de situar o positivismo jurídico normativo no debate contemporâneo a respeito do positivismo jurídico, foram apresentadas as principais tendências dessa teoria, isto é, o positivismo jurídico inclusivo, o positivismo jurídico exclusivo e o positivismo normativo. Na seção seguinte, passou-se a expor a teoria de Waldron, tanto no que diz respeito às suas teses acerca da democracia, da autoridade e do modo de lidar com os desacordos morais e políticos, quanto suas teses a respeito de uma teoria positivista normativa e democrática.

O estudo da teoria da democracia e da teoria do direito de Waldron mostra uma proposta bastante empenhada em conectar o positivismo jurídico com a tradição política normativa, notadamente, a autoridade do direito com a dignidade e a legitimidade da legislação democrática, concebida como aquela aprovada segundo procedimentos deliberativos dentro de um poder legislativo representativo e respeitoso para com os desacordos. Essa é uma postura de grande relevância para a filosofia e para a teoria do direito na atualidade, sobretudo diante da marginalização, ou em alguns casos até mesmo da criminalização da política.

No âmbito da teoria do direito a principal questão que se coloca é em que medida a proposta de um positivismo jurídico normativo se afirma como uma teoria do direito ou permanece no campo de estudo da filosofia do direito, justamente em razão de seu caráter prescritivo ou normativo. Com certeza, as teses defendidas por Waldron estabelecem um modelo de como deveria ser o desenho institucional para se assegurar os valores de sociedades livres e democráticas. Segundo ele, é certo que isso é uma tarefa da filosofia política e da filosofia do direito, mas entende ser fundamental que essa empreitada seja abraçada também pela teoria do direito, ou seja, no seio da discussão acerca da validade, da autoridade, da interpretação e da aplicação do direito. 


\title{
NORMATIVE POSITIVISM IN JEREMY WALDRON'S PERSPECTIVE
}

\begin{abstract}
This article presents and discusses the normative legal positivism according to Jeremy Waldron's theory. First, the main trends of contemporary legal positivism are presented, namely: inclusive, exclusive and normative positivism. In a second moment the analysis concentrates on Jeremy Waldron's normative legal positivism, focusing on the justification of the authority of law and also on the methodological approach of this trend. Finally, it is argued that Waldron's theory seeks to develop a democratic theory of law.
\end{abstract}

Keywords: Jeremy Waldron, Jurisprudence, Normative Positivism, Democracy. Disagreement

\section{REFERENCIAS}

ARENDT, Hannah. Origens do Totalitarismo. Trad. Roberto Raposo. São Paulo: Companhia das Letras, 1989.

BELLAMY, Richard. Political Constitutionalism: A republican defense of the constitutionality of democracy. New York: Cambridge University Press, 2007.

CAMPBELL, Tom. Prescriptive legal positivism: law, rights and democracy. London: UCL Press, 2004.

COLEMAN, Jules. Incorporationism, conventionalism, and the practical difference thesis. In: COLEMAN, Jules (Org.). Hart's postscript. Essays on the postscript of the concept of law. Oxford: Oxford University Press, 2001, p. 99-147.

Negative and positive positivism. In: COLEMAN, Jules (Org.). Markets, Morals and the Law. Oxford: Oxford University Press, 1998, p. 3-27.

DIMOULIS, Dimitri. Positivismo Jurídico: introdução a uma teoria do direito e defesa do pragmatism jurídicopolítico. São Paulo: Método, 2006.

DWORKIN, Ronald. Levando os direitos a sério. Tradução Nelson Boeira. São Paulo: Martins Fontes, 2002. The Model of Rules. The University of Chicago Law Review, v. 35, 1967, p. 13-46.

HART, H.L.A. O conceito de direito. Pós-escrito organizado por Penelope A. Bulloch e Joseph Raz; tradução de Antônio de Oliveira Sette-Câmara; revisão da tradução Marcelo Brandão Cipolla; revisão técnica Luiz Virgílio Dalla-Rosa. São Paulo: WMF Martins Fontes, 2009.

KRAMER, Matthew H. Where Law and Morality Meet. Oxford: Oxford University Press, 2004.

MAcCORMICK, Neil. A Moralistic Case for A-Moralistic Law. In: Valparaiso University Law Review, v. 20, n.1, 1985, p. 1-41.

MARMOR, Andrei. Exclusive Legal Positivism. In: COLEMAN, Jules et al. (Orgs.). The Oxford Handbook of Jurisprudence and Philosophy of Law. Oxford: Oxford University Press, 2002, p. 104-124.

Positive Law and Objective Values. Oxford: Oxford University Press, 2001. 
RAWLS, John. Uma Teoria da Justiça. Tradução Jussara Simões; revisão técnica Álvaro de Vita. São Paulo: Martins Fontes, 2008.

RAZ, Jospeh. The authority of Law: Essays on Law and Morality. Oxford: Clarendon Press, 1979. The Morality of Freedom. Oxford: Clarendon Press, 1986.

SEBOK, Anthony. Legal positivism in American Jurisprudence. Cambridge: Cambridge University Press, 1998.

STACEY. Richard. Democratic Jurisprudence and Judicial Review: Waldron's Contribution to Political Positivism. In: Oxford Journal of Legal Studies, v. 30, n. 4, 2010, p. 749-773.

VOLPATO DUTRA, Delamar José. Positivismo jurídico inclusivo e positivismo jurídico exclusivo. In: BUENO, Roberto (Org.). Racionalidade, Justiça e Direito: Ensaios em Filosofia do Direito. Uberlândia: EDUFU, 2013, p. 193-209.

WALDRON, Jeremy. A majority in the lifeboat. In: Boston University Law Review, Vol. 90, 2010, pp. 1043-1057. Can There Be a Democratic Jurisprudence. In: Emory Law Journal, v. 58, 2008, p. 675-712. Constitutionalism - A Skeptical View. In: T. Christiano/ J. Christman (orgs.). Contemporary Debates on Political Philosophy. Malden, Massachussetts: Blackwell Publishing, 2009, pp. 267-282. Kant's legal positivism. In: Harvard Law Review, v.109, n.7, 1996, p. 1535-1566. Law and Disagreement. New York: Oxford University Press, 1999a. Liberal rights: collected papers, 1981-1991. Cambridge: Cambridge University Press, 1993. Normative (or Ethical) Positivism. In: COLEMAN, Jules (Org.). Hart's Postscript. Essays on the Postscript of 'The Concept of Law'. Oxford: Oxford University Press, 2001, p.410-433. The Core of the Case Against Judicial Review. The Yale Law Journal, 115, 2006, p. 1346-1406. The Harm in Hate Speech. Cambridge/London: Harvard University Press, 2012.

WALUCHOW, W.J. Inclusive legal positivism. Oxford: Clarendon Press, 1994.

Trabalho enviado em 22 de julho de 2015.

Aceito em 28 de setembro de 2015. 